\title{
TEMATOLOGI: PEMBACAAN TEORITIS TERHADAP SALAH SATU METODE PENELITIAN SASTRA BANDING CLAUDIO GUILLEN
}

\author{
Lusia Kristiasih Dwi Purnomosasi \\ Pendidikan Bahasa Inggris IKIP PGRI Madiun \\ Jl. Setia Budi 28 Madiun Jawa Timur \\ Email: lusiakdp@gmail.com
}

\begin{abstract}
Abstrak
Kemunculan studi sastra banding Claudio Guillen mempunyai dasar latar belakang yang jelas, yaitu terwujudnya Weltliteratur. Dengan mengkritisi pengertian sastra dunia Goethe tersebut, Guillen memformulasikan metode pengkajian sastra banding. Inspirasi dari Goethe menghasilkan dasar pemikiran teorinya, yaitu the one and the many dan the universal and the local dimana di dalamnya memerlukan dialog (internasionalitas) dengan perspektif sosial dan historis untuk menemukan struktur diakronis. Struktur diakronis berguna untuk mengidentifikasi supranasional dalam data primer yang dibandingkan. Seorang peneliti dapat melakukan penelitian dengan 5 basis, salah satunya tematologi. Dalam tematologi, motif utama tema menjadi alat dialog dalam internasionalitas di atas.
\end{abstract}

Kata kunci: sastra banding, internasionalitas, struktur diakronis, supranasionalitas

\section{Abstract}

Comparative literature study by Claudio Guillen has basic reason namely Weltliteratur. Guillen did criticism upon it to formulate his own method on comparative literature research. Goethe has inspired him to create the basic assumsion of his theory; the one and the many and the universal and the local as well, upon which the internationality by socio-historical perspectives is conducted to identify the diachronic structure. It will reveal the supranationality within the primary data being compared. A researcher will stand on 5 principles, one of which is thematology where a principle motif of a theme lies as a means of dialog in internationality.

Keywords: comparative literature, internationality, diachronic structure, supranationality

\section{Pendahuluan}

Claudio Guillen dalam bukunya yang berjudul The Challenge of Comparative Literature yang diterjemahkan oleh Cola Franzen (1993) telah menambah khazanah teori sastra banding yang sudah berkembang sebelumnya. Pada buku ini Guillen menawarkan konsep-konsep sastra banding dan alasan historis yang mendasari tumbuh dan berkembangnya studi sastra banding. Selain itu, buku ini juga menjelaskan metode analisis sastra banding dan kritikannya terhadap penelitian yang telah dilakukan oleh orang lain. Jangkauan investigasi analisisnya cukup luas sehingga penulis membatasi pembacaan pada bagian tematologi.

Kajian sastra banding dimulai pada dua dan tiga dekade abad ke-19 di Prancis. Rene Wellek dalam bukunya History of Modern Criticism: 1750-1950 (1955-1965) disebut Guillen sebagai tokoh penyumbang ide sastra banding dewasa ini karena idenya adalah menghapuskan pemilahan antara kritik, sejarah, dan teori. Selain itu, sastra banding yang dirumuskan Guillen merupakan reaksi dari perkembangan kajian sastra banding yang sudah dilakukan selama ini. Dua hal ini menjadi inspirasi bagi Guillen (1993:104-105) untuk menyusun teori sastra bandingnya. Guillen menjelaskan identitas kajian sastra banding tidak bergantung pada tindakan peneliti sematamata, yaitu mengkaji karya- karya sastra dari sudut pandang internasionalitas, menggunakan pendekatan tertentu, dan memakai teori sastra tertentu. Menurut Guillen (1993:3) kajian sastra banding selama ini berorientasi pada kegiatan menguji karya sastra dari sudut pandang internasionalitas saja. Padahal, identitas sastra banding tidak semata-mata tergantung pada bagaimana pelaku penelitian sastra banding berkegiatan membandingkan. Selanjutnya, 
seorang pelaku penelitian sastra banding menghindarkan diri dari satu atau dua polaritas meskipun sastra banding mengonsentrasikan diri pada polaritas. Hal yang dimaksud polaritas pada kutipan ini adalah kelokalan dan keuniversalan yang diterangkan pada bab II yang berjudul the local and the universal pada bagian pertama buku Guillen. Spesialisasi atas satu wilayah atau nasionalitas tidaklah cukup untuk melakukan kegiatan pembandingan. Maka, internasionalitas mengandung arti tindakan menghubungkan satu karya sastra wilayah yang satu dengan yang lain (Guillen, 1993: 6). Kata nation yang bermakna wilayah dijelaskan oleh Guillen pada kalimatnya yang berbunyi, "...nation — nationality, country, region, city_because ...." (Guillen, 1993: 5). Selain itu, makna internasionalitas juga teridentifikasi pada pembahasan tentang weltliteratur pada bab VI, yang selanjutnya diuraikan pada subbab di bawah nanti.

Keberatan yang disampaikan Guillen tentang penggunaan teori sastra tertentu oleh peneliti sastra banding lain pada kajian sastra banding ditulis pada kutipan berikut,

"On such occasions, literary theory cannot be allowed to do what I have condemned at various times in this book, namely, to fly off heedlessly toward a universal model based only on knowledge of a single nation, a single writer, or a single period, thereby creating an absolute from the lesson of a single example" (Guillen, 1993: 323).

Menurutnya, teori sastra tidak berperan banyak bagi pelacakan sebuah model yang universal jika hanya berbasis pada satu wilayah, satu pengarang, atau satu periode. Hal ini dapat membentuk kebenaran yang absolut dari satu contoh kajian saja. Dari kutipan ini pula, secara implisit Guillen mengungkapkan pandangannya tentang kelemahan kajian sastra banding sebelumnya.

Kelemahan lainnya dapat ditemukan pada bab yang berjudul taxonomies. Pada awal bab tersebut, Guillen mengidentifikasi empat fokus investigasi sastra banding di abad ke-19 seperti berikut: (1) tematik atau studi tematema folklorik, (2) morfologi atau studi tentang genre dan bentuk, (3) identifikasi sumber atau crenologia, (4) studi yang berkenaan dengan intermediaries, seperti jurnal, terjemahan, dan sebagainya. Guillen mendeteksi kelemahan pada praktik perbandingan itu, yaitu terletak pada terlupakannya unsur sejarah sastra dan konfigurasinya (periode, gerakan, dan gelombang).

Dapat ditarik kesimpulan bahwa apabila kenyataan-kenyataan di atas diterapkan pada kajian sastra banding Guillen maka akan terjadi kemandegan. Hal ini disebabkan oleh karya sastra yang sudah pernah dikaji menjadi terkungkung pada hasil penelitian yang teridentifikasi saja. Padahal kajian sastra banding, Guillen melanjutkan, adalah kajian yang mewadahi dialog antara unity dan diversity yang memberikan stimulus komparatisme untuk fokus pada konfrontasi terbuka antara kritik/ sejarah sastra dengan teori sastra (Guillen, 1993: 70-71). Konsep ini terdapat pada bab X buku Guillen tentang model supranasionalitas terutama model yang ketiga (pembahasannya ada pada subbab di bawah).

Jadi, kajian sastra banding yang disusun oleh Guillen adalah tindakan investigasi yang melibatkan studi sistematis tentang keterkaitan supranasionalitas (Guillen, 1993: 3). Supranasionalitas, merujuk pada harapan Guillen, bekerja dengan jalan penjelajahan "beyond cultural nationalism, beyond using literature in nationalistic ways...for ideological ends" (Guillen, 1993:4). Supranasionalitas dapat ditempuh dengan melacak ciri-ciri literary communication, primordial chanel-nya, metamorfosis dari genre, dari form, dan dari tema. Oleh karena itu, dalam supranasionalitas terdapat refleksi sejarah kesastraan, kondisi yang terbangun, ciri-ciri, profil era, dan makna (Guillen, 1993:4). Semua ini ditempuh Guillen oleh sebab mimpinya tentang sastra dunia (diuraikan pada bab VI tentang weltliteratur) seperti yang disampaikan oleh Goethe.

Ide-ide dasar teori sastra banding oleh Guillen mempunyai beberapa latar belakang 
kemunculan. Dalam buku Guillen ditulis 11 hal pembicaraan yang memicu munculnya studi sastra banding. Akan tetapi, pembacaan ini tidak menghadirkan semua bahan pembicaraan tersebut. Hal-hal yang ditampilkan hanya hal-hal mendasar yang berhubungan dengan konsep the local and the universal, the one and the many, weltliteratur, dan taxonomy. Konsep-konsep terpilih ini mendasari pengertian akan adanya the unity dan the diversity.

\section{The Local and the Universal}

Istilah the local and the universal diperkenalkan oleh Guillen dengan maksud memberikan tanda terjadinya dua ketegangan konseptual yang memicu munculnya serangkaian oposisi yang terjadi pada situasi yang berbeda. Misalnya, ketegangan antara keberadaan yang ada dan tiada, yang diraih dan yang diinginkan, yang hadir saat sekarang dan yang abadi, dan sebagainya. Jadi, arti kata the local bukan sebuah lokal/tempat, bukan pula sebuah nation, yaitu nasionalitas, negara, wilayah, dan kota. Ketegangan ini berkaitan dengan keberadaan seni. Seni tidak terikat pada tempat dan waktu atau milik perseorangan maupun kelompok tertentu. Seni adalah image (citraan). Oleh karena itu, seni merupakan the forever in the now di mana posisi karya seni ada pada branches of the only tree (Paz, 1983: 21; Esteban, 1979: 43 dalam Guillen, 1993: 6).

Untuk menyederhanakan konsep di atas, Guillen mengusulkan empat opsi utama sehubungan dengan keberadaan seni dan polaritas yang membayanginya. Pertama, kesenjangan antara kecenderungan artistik dan tuntutan sosial. Kedua, perbedaan antara halhal yang praktis dan teoretis. Ketiga, perbedaan di antara individual dan sistem. Keempat, ketegangan antara yang lokal dan universal (Guillen, 1993: 6).

\section{The One and the Many}

Konsep the one and the many dimulai dari kongres sastra banding pada 1971. Pada kongres tersebut muncul usulan tentang perlunya dibentuk studi East/West. Keberadaan karya- karya sastra yang berada pada kawasan "timur" dipandang sebagai "terpencil". Kemudian, timbul pikiran untuk mempertanyakan kontak dan pengaruh karya sastra di luar kawasan timur, yaitu "barat" terhadap karya-karya sastra timur, Asia dan Afrika. Guillen mengidentifikasi bahwa studi East/West adalah bidang di mana dialog antara unity dan diversity menjadi hidup dan menjadi jelas. Dialog terjadi karena ada dua koordinat, yaitu ruang dan waktu (Guillen, 1993: 17).

Berkaitan dengan ruang hubungannya dengan eksistensi karya sastra, beberapa hal perlu dipertanyakan. Pertama, apakah dialog hanya terjadi pada karya-karya sastra yang terpisah oleh jarak, oleh peradaban yang tidak saling mempengaruhi? Kedua, bagaimana dengan karya-karya sastra yang berada pada wilayah yang berdekatan dan tidak begitu banyak menunjukkan perbedaan? Ruang dan waktu menciptakan ciri-ciri sastra nasional yang memang mudah ditandai, tetapi sulit untuk dimengerti. Atas dasar inilah, dialog perlu diadakan supaya terjadi komunikasi bagaimana karya-karya sastra mengalami perbedaan, kontras, dan omissions (penghilangan). Lebihlebih, tema yang sama atau berpotensi "universal" akan menjadi aspek yang sangat terbuka bagi perdebatan. Pentingnya dialog tercantum seperti kutipan di bawah ini,

Thus, investigation by way of dialogue helps us to perfect our knowledge of all the components under consideration, as long as the effort doesn't become bogged down or fail. (Guillen, 1993: 17)

Investigasi yang dilakukan untuk memahami dan mempelajari aspek-aspek di atas adalah dengan cara dialog. Maka, sastra banding mempunyai andil penting untuk meyakinkan bahwa tema berada dalam framework supranasionalitas. Guillen memberikan contoh kasus antologi untuk meyakinkan bahwa keterbatasan budaya dan dunia sastra merupakan kenyataan yang tidak mengarah pada inklusivitas, tetapi eksklusivitas realitas yang lebih luas. Jadi, dialog terjadi antara lokalitas dan 
globalitas. Berkenaan dengan koordinat waktu, dialog terjadi antara evolusi dan kontinuitas. Tidak semua hal berevolusi dan tidak semua hal kontinu. Demikian pula dengan tema. Tema terpecah-pecah dan terbelah menjadi bagian-bagian lain atau berevolusi, tetapi tema yang sama pada suatu saat kadang menghilang (pengertian ommisions pada pembicaraan di atas). Semua ini disebabkan oleh perubahan. Bentuk, kata-kata, kepribadian mengalami perubahan. Demikian halnya apa yang dirasakan laki-laki dan perempuan, apa yang dibicarakan orang, dan nilai. Semua perubahan itu hanya dapat terlacak dengan menghadirkan sejarah. Maka, sastra banding memerlukan jasa sejarah. Oleh karena itu, posisi dialog menjadi sentral pada sastra banding Guillen. Di satu sisi, terdapat struktur yang mendasar pada karya sastra yang berbeda melalui waktu. Di sisi yang lain, ada perubahan, evolusi, sejarah sastra, dan masyarakat (Guillen, 1993: 18).

Dengan adanya peran dialog koordinat ruang dan waktu, karya sastra ditempatkan pada posisi yang unik dalam konteks sastra nasional. Ada perubahan pandangan, yaitu (1) karya sastra, dewasa ini, tidak dapat dibatasi pada satu tradisi saja yang dinyatakan oleh satu orang individu; (2) sejarah sastra tidak dapat ditempatkan hanya pada satu teori yang final; (3) karya sastra tidak dapat terkungkung oleh persepsi pembaca yang membatasi diri pada analisis teks-teks sastra yang berdiri sendiri. Dengan kata lain, karya sastra tidak dapat diletakkan pada pandangan yang sempit pada satu metode dan satu teori-kritik, atau satu era dan satu genre. Sastra tidak dapat dipandang sebagaimana yang dihasilkan dan diajarkan negara-negara Eropa Barat dan Amerika. Sastra tidak dapat dikatakan sebagai sastra atau bukan sastra berdasarkan kejadian tertentu dan selera tertentu (Guillen, 1993: 19).

Guillen membuktikan perubahan konsep keberadaan karya sastra di atas dengan menyebutkan apa yang sudah dilakukan oleh novelis dan linguis abad ke-18. Perubahanperubahan terjadi di akhir abad ke-18 ketika karya sastra mengalami dinamika pergerakan dua kutub yang saling tarik ulur. Oleh karena pergantian generasi, sistem, teori, sejarah, dan antologi, karya sastra membentuk dirinya sendiri berulang-ulang dari bentuk yang dahulu ke bentuk yang terbaru lalu kembali lagi ke bentuk yang lama dan seterusnya. Kedinamisan ini dipengaruhi oleh ketegangan antara integritas dunia yang ditandai oleh majunya ilmu pengetahuan alam dan perkembangan teknologi, dan pluralitas dunia sosial, politik, budaya, dan mental. Kondisi ini membentuk horizon kaum humanis dan para pencipta karya sastra (Guillen, 1993: 22).

Dinamika dan perubahan sosial mempengaruhi dinamika dan perubahan karya sastra. Diperlukan dialog untuk membandingkan dan mencari ide besar mengapa terjadi dinamika dan perubahan. Guillen meyakinkan bahwa studi sastra adalah sebuah meta-upaya untuk mengaitkan, menemukan, atau menghadaphadapkan karya- karya yang tercipta pada wilayah dan momen yang sangat jauh berbeda dan terpisah: the one and the many (Guillen, 1993: 23).

\section{Weltliteratur}

Istilah weltliteratur, diungkapkan pertama kali oleh Goethe-penulis Jerman-pada 1827, membawa penafsiran yang ambigu. Guillen menuliskan ada tiga kemungkinan arti kata tersebut berdasarkan apa yang selama ini ditafsirkan oleh penulis lain. Oleh karena itu, Guillen memulai diskusinya tentang weltliteratur dengan menerjemahkannya sebagai "literature of the world" (Guillen, 1993: 39). Arti pertama, kehadiran pekerja seni sastra dan karya sastra yang menjadi "mendunia" dan untuk seluruh dunia bagi siapa saja. Tidak peduli apakah ada batasan wilayah, karya sastra diciptakan untuk generasi sekarang dan yang akan datang di negara mana pun. Arti kedua, karya sastra dengan perjalanan tumbuh kembangnya, dengan penerimaan dan penolakannya oleh pembaca, kritikus, atau penerjemah, telah bersikulasi di seluruh dunia. Karya sastra telah menciptakan jembatannya sendiri untuk menghubungkan karya sastra yang satu dan yang lain. Arti ketiga, 
karya sastra merefleksikan dunia, berbicara kepada seluruh umat manusia tentang ekspresi pengalaman manusia yang terdalam, mendasar, dan tak lekang dimakan zaman. Menurut Guillen, dua pengertian pertama mengacu pada perwujudan internasionalitas, sedangkan yang ketiga dicirikan sebagai supranasional (Guillen, 1993: 40).

Goethe, menurut penjelasan Guillen berikutnya, sudah pernah menyatakan bahwa tiba saatnya bagi setiap orang untuk keluar dari keterpencilannya dan menghirup udara dari dunia milik orang asing. Tidak bisa tidak, harus diciptakan sebuah cara untuk memenuhinya, yaitu dengan jasa penerjemahan dan studi bahasa asing. Dengan begitu, karya ciptaan pengarang besar dapat terbaca secara luas dan menjangkau bermacam-macam pembaca. Jadi, di masa Goethe telah tercipta international exchange (pertukaran secara internasional). Pada masa sekarang, praktik ini disebut dengan resepsi sastra. Resepsi sastra menjadi semakin menginternasional. Dengan begitu, Goethe membuat jelas fenomena era modern dengan tanda-tanda terciptanya kemudahan berkomunikasi.

Dialog antarkarya sastra telah dimulai. Ide ini dapat dengan jelas terbaca pada uraian di atas. Dialog era awal modern bisa diarahkan pada dialog antara dunia sastra dan dunia perdagangan, antara relasi pertumbuhan ekonomi dan hubungan perkembangan budaya. Sebagai hasil dari sebuah perubahan, kehadiran kaum borjuis menyumbangkan efek positif bagi perkembangan karya sastra. Borjuis mampu bergerak tidak hanya secara politis, tetapi juga secara ekonomis dan kultur. Efek kehadiran borjuis adalah wujud ideal masyarakat di abad ke-18. Masyarakat berkembang menjadi lebih toleran, dan komponen-komponen kemasyarakatan tidak lagi terisolasi satu sama lain (Guillen, 1993: 41). Inilah yang membuka pintu dialog antarkarya sastra.

Guillen mengatakan bahwa ide Goethe yang menghubungkan relasi sastra dan ekonomi terbukti dengan munculnya Communist Manifesto pada 1848 oleh Karl Marx. Faktanya, produksi karya-karya intelektual dan produksi berupa material menjadi "milik umum". Jadi, sastra dunia akan terbentuk dari sastra lokal (Guillen, 1993: 42 mengutip Vajda (1964: 338-339)). Hal ini mengandung dua pengertian hubungan, yakni antarbangsa (internasional) dan antarwaktu (intertemporal). Hubungan ini pula yang menjadi kata kunci pada konsep internasional dan supranasional Guillen. Lokalitas dan makna yang muncul menumbuhkan dorongan bersastra (ide ini ada di pembahasan the one and the many). Maka, perbedaan internasional dan supranasional tidak akan saling memisahkan melainkan saling melengkapi (Guillen, 1993: 42). Dengan demikian, semakin jelaslah pengertian internasionalitas yang disinggung di awal, yaitu internasionalitas tidak berbicara tentang dominasi kemenangan sebuah lembaga di atas keberanekaan di dunia ini. Internasionalitas berbicara tentang kontak antara perbedaan lokal. Kontak ini mengakibatkan tidak hanya kemungkinan perbedaan-perbedaan, tetapi juga konfirmasi nilai-nilai umum yang berlaku dan pertanyaan-pertanyaan atasnya. Nilai umum ini mengarah pada pengertian supranasional.

Dikatakan di awal bahwa Guillen menciptakan konsep sastra banding karena ingin dan terinspirasi oleh sastra dunia Goethe. Investigasi sampai tahap supranasional adalah cara yang ditempuh sebab di dalamnya ada kontak, relasi, dialog, dan nilai. Guillen (1993: 45) mengutip Marino (1975: 68) tentang apa yang dilontarkan Goethe tentang mencairnya perbedaan tempat dan waktu karya sastra tercipta. Tidak ada lagi posisi yang berbeda di antara mereka. Jalinan ini terbentuk karena dialog. Oleh karena itu, "universal literature"menjadi wadah komunikasi bagi semua karya sastra. Komunikasi dan komunitas ini akan menampakkan satu kesadaran budaya dunia yang permanen dan simultan. Maka, jalinan dialog adalah internasionalitas dan kesadaran budaya adalah supranasionalitas dalam konsep Guillen. 


\section{Taksonomi}

Taxonomy adalah pengklasifikasian. Guillen mengidentifikasi klasifikasi kajian sastra banding dan mengkritisi keberadaan penelitian-penelitian yang sudah dilakukan. Di antara tokoh-tokoh yang disebut dapat disimak berikut ini. Renato Poggioli (1943) menyebutkan empat arah investigasi sastra banding dalam artikelnya, yaitu (1) tematik atau studi tema folklore, (2) morfologi atau studi genre dan bentuk, (3) identifikasi sumber, dan (4) pengujian fortuna pengarang (Guillen, 1993: 95). Klasifikasi investigasi ini mempunyai kelemahan. Kelemahan terletak justru pada hubungan dua kutub yang diperbandingkan, karya sastra dan estetika. Di antara kedua kutub ini tercipta adu komentar, persilangan pendapat, dan kritikan yang terisolasi dari dunia di luarnya. Kenyataan ini tidak mengarahkan sastra banding pada entitas yang berupa supranasional atau kontinuitas sejarah, tetapi pada sejumlah akumulasi pembelajaran yang tampil bagus, bahkan elegan, namun hanya akumulasi dan tidak lebih dari itu (Guillen, 1993: 100). Ditambahkan oleh Guillen bahwa investigasi sastra banding yang ideal adalah objek kajiannya bersumber pada buku, yaitu karya sastra. Inspirasi Guillen (1993: 103) ini berasal dari pendapat A.M. Bassy (1973: 18) tentang buku sebab buku memungkinkan terjadinya proses psikologis sekaligus sosiologis. Pembaca mereaksi buku dengan pikiran dan interpretasinya terhadap apa yang dibaca dan yang dialami. Menurut Guillen, buku yang tercipta merupakan perwujudan tentang apa yang dialami sebagai karya tulis yang original. Dari titik ini, terjawablah ideal Guillen tentang material sastra banding, yaitu membandingkan antarkarya sastra.

Selanjutnya, Guillen mengungkapkan ketertarikannya terhadap teks (berwujud karya sastra) sebagai objek studi sastra banding. Ia mengatakan bahwa ia lebih tertarik mempelajari bagaimana teks, bentuk, atau genre dipresentasikan dan diorganisasikan. Di sana pikiran-pikiran tentang teks, bentuk, dan genre tarik-menarik antara unity yang terlihat pada wacana atau kesadaran pembaca dan perbedaan-perbedaan secara spatialhistorical yang tidak terhitung jumlahnya, begitu nyata dan jelas dalam dunia sastra. Guillen mempertanyakan pada diri sendiri bagaimana ide dari gaya individu terhubung dengan konsep gaya kolektif (1993: 104).

Oleh karena itu, Guillen menyusun teori sastra bandingnya dengan beberapa klasifikasi seperti halnya penulis-penulis lain sastra banding sebagai berikut. Henri Peyre (1952) menghidupkan kembali tematologi sebagai tanda kebaruan minat pada mitos dan simbol pada bidang antropologi dan psikoanalisis.

Harry Levin (sekitar 1952) menekankan pada (1) studi terjemahan, tradisi, dan gerakan, (2) transformasi genre melalui sejarah, (3) elaborasi "repertoire of themes". Owen Alridge (1969) mengemukakan klasifikasi kajian sastra banding dalam jurnalnya yang berjudul Comparative Literature Studies, yakni (1) literary criticism, (2) literary movement, (3) literary themes, (4) literary forms, (5) literary relation. Francois Jost (1974) menggolongkan investigasi sastra banding dalam buku Introduction to Comparative Literature, yakni (1) relations: analogies and influences, (2) movement and trends, (3) genres and forms, (4) motifs,types, themes (Guillen, 1993: 103). Guillen (1993: 105) mengusulkan lima kelas investigasi; (1) genology, (2) morphology, (3) thematology, (4) internationality, (5) bistoriology. Selanjutnya, kelaskelas ini akan dibatasi hanya pada tematologi.

\section{Model Supranasional}

Tiga model supranasional yang dijelaskan oleh Guillen berikut ini adalah kerangka konseptual yang tidak menutup kemungkinan jumlah model bertambah sepanjang ada kerangka konseptual yang dapat dipertanggungjawabkan. Model A merupakan model yang terkini. Model A adalah studi tentang fenomena dan supranasional yang berkaitan dan mengimplikasikan internasionalitas. Model A mengarahkan kajian, baik kontak genetik maupun relasi lain antara pengarang dan proses yang terjadi pada national sphere atau common cultural premises (Guillen, 1993: 69). 
Model B mempelajari segala fenomena atau proses yang terjadi pada peradaban yang berbeda. Peradaban tersebut sama sekali tidak memiliki ketergantungan satu sama lain. Semua ini dikumpulkan untuk dikaji. Pengujian ini ditimbang dan dibawa ke arah common sociobistorical conditions. Model kedua ini mengangkat keberadaan proses dan pertumbuhan sosioekonomi yang berkembang sebagai basis. Kedua basis tersebut memungkinkan terjadinya gejala politik yang melanda masyarakat dan peradaban yang berbeda untuk disambungkan dan dibandingkan (Guillen, 1993: 70).

Model C dilakukan dengan menggantungkan kajian pada prinsip dan tujuan teori sastra. Dengan demikian, model C memperbaharui entitas supranasional dari beberapa fenomena yang secara genetik independen. Keterpisahan adalah aspek utama yang dimanfaatkan untuk investigasi atas masalah yang harus diselesaikan. Model ketiga ini memungkinkan terjadinya dinamika; pergerakan ke arah bersikontra mulai tampak, atau pengetahuan baru atau fakta-fakta yang belum terpublikasikan terdeteksi. Hal ini akan menjadi tantangan bagisebuah teori. Olehkarena itu, struktur diakronik dan perkembangannya diuji seperti yang ditunjukkan oleh kajian-kajian ideologis, keberadaan genre modern, atau gaya menulis sepanjang kerangka konseptualnya adalah teori sejarah sastra (Guillen, 1993: 70).

\section{Tematologi: Sebuah Pilihan Metode}

Tema, menurut selera Guillen, adalah salah satu alat menuju penemuan supranasional. Pandanganini ditempuh dengan merekonstruksi pengertian tema yang sudah ada. Pengertian tema yang terdahulu mengarah pada apa yang dikatakan atau ingin dikatakan oleh pengarang. Oleh karena itu, tema dapat dikatakan sebagai pokok pikiran cerita sehingga identifikasi tema diwujudkan dalam kalimat yang mewakili ide seluruh cerita (Schuster, 1966:88; Yanni, 1994: 70). Guillen (1993: 192) mengkritisinya dengan melakukan rekonstruksi bahwa tema adalah apa yang digunakan pengarang untuk mengatakan sesuatu, "Not what the poem says, but what it uses to say it". Diperjelas lagi di halaman lain, " [...] the theme is what the writer modifies, modulates, overtunes, not what he says but what he uses to say with[...]"( Guillen, 1993: 197). Guillen juga mengutip Manfred Beller (1970: 2) yang mengatakan bahwa tema adalah elemen yang membentuk sebuah karya sastra in a perceptible way (dapat membentuk kesadaran dan dinikmati). Hal ini mempunyai alasan bahwa pada awal proses penciptaan, pengarang masuk dalam kegelapan, bahkan ketidaksadaran. Oleh karena itu, dibutuhkan Objekt untuk merealisasikannya dan membuat karya itu konkret (1993: 192). Sebenarnya, kata what pada kutipan hlm. 192 dan 197 yang dimaksudkan Guillen sama dengan kata objekt oleh Schiller. Maka, tema ala Guillen dapat dikatakan sebagai "lembaga" yang memerlukan agen untuk menggerakkan lembaga tersebut (pada uraian selanjutnya disebut motif). Lembaga itu berbentuk objek. Jadi, objek yang dimaksud adalah tema. Dengan demikian, tema merupakan elemen untuk mengidentifikasi supranasional dengan alasan bahwa elemen tematik dapat menghubungkan satu karya sastra dengan yang lain (intertekstual) dan momen-momen yang berkesinambungan dalam sebuah karya sastra (intratekstual) (Guillen, 1993: 196).

Mengingat tema adalah objek cerita, keberadaan tema menjadi relatif sebab tema memungkinkan untuk dimodifikasi, diperluas, dan diulang (Guillen, 1993: 192). Selain itu, wujud dari objek cerita dapat dikelompokkan menjadi dua, yaitu image dan motif (pengertian motif yang ini berbeda dengan motif oleh Elizabeth Franzel pada uraian selanjutnya). Selanjutnya, Guillen menampakkan alternatif dua bentuk kelompok objek tersebut menjadi beberapa wujud, yaitu images (seperti warna), topoi dan commonplaces, karakteristik sebuah ruang dan latar (seperti kota besar pada novel modern), moral dan sosial atau profesional (seperti tokoh-tokoh ilmu pengetahuan dan ajarannya), dan motif (seperti keserakahan) (Guillen, 1993: 196). Pengklasifikasian senada dilakukan oleh penulis lain, yaitu S.S. Prawer (1973: 99-100) yang mengelompokkan tema 
menjadi lima grup seperti kutipan berikut,

"first, the literary representation of the natural phenomena (the sea), the fundamental conditions of human existence (the dream), and perennial human problems; second, the recurrent motifs of literature and folk:lore (the three wishes, the magic ring); third, recurring situations (the conflict of son with father); fourth, social types, or professional and moral ones (the gentleman, the criminal, the traveler); and finally, characters derived from mythology, legends, and literature itself (Prometheus, Siegfried, Hamlet)" (Guillen, 1993: 198).

Terlihat beberapa perbedaan selain kesamaan antara Guillen dan Prawer. Akan tetapi, perbedaan ini tidak dimaksudkan untuk dijadikan polemik atau dikritisi melainkan memperkaya "wujud" objek cerita atau tema. Kenyataan ini memperkuat sekaligus membuktikan pernyataan sebelumnya yang menyatakan bahwa "the limits of a theme,..., are very relative ... when a theme is modified, broaden, or repeated" (Guillen, 1993: 192) sebab "the writer modifies, modulates, overtunes" (Guillen, 1993: 196). Konsep Guillen ini mempunyai dampak pada kehadiran tematologi sebagai salah satu bidang investigasi pada kajian sastra banding. Mengenai pentingnya tematologi, nature, dan cara kerjanya akan diuraikan pada paragrafparagraf selanjutnya.

Kemampuan pengarang untuk memodifikasi, mengubah, mengadopsi, dan melahirkan kembali sebuah tema mengakibatkan diversity (keberanekaan). Diversitas ini memerlukan connection (ketersentuhan atau kebersinggungan). Guillen menyebutkan dua cara untuk mencapai connection ini dengan mengadopsi ide Prawer, yaitu dengan historical nature dan polarity. Berikut ini disampaikan peran history dan polarity.

Peran sejarah digunakan untuk mendeteksi mana (wujud objek seperti disinggung di atas) yang nyata dan tidak. Untuk mempermudah, sebut saja mana yang perennial dan mana yang bukan. Perbedaannya adalah ada di mana. Dengan demikian, peran sejarah berbicara tentang evolusi tema, keasliannya, dan kemunculannya kembali dalam wujud yang berbeda dengan asalnya. Jika proses ini terdeteksi maka struktur dari kemungkinankemungkinan yang menyebabkannya dapat dimanifestasikan. Jadi, hanya sejarah yang dapat bekerja seperti ini.

Polaritas berbicara tentang dua hal yang berbeda, misalnya polaritas antara fenomena alam, seperti bunga, air, dan sebagainya dan a dream of a Golden Age. Selanjutnya, polaritas ini memunculkan pertanyaan-pertanyaan semacam bagaimana dua hal tersebut saling berbaur dan mempengaruhi, mediator apa yang memfasilitasi ke-ter-saling-hubungan itu, kapan fenomena alam itu selesai dan kapan fenomena budaya atau masyarakat dimulai.

Guillen memberikan penjelasan tentang uraian konsepnya tersebut dalam contohcontoh yang bermacam-macam, salah satunya akan dicantumkan peneliti di sini. Puisi Pedro Salinas yang berjudul San Juan de Puerto Rico: El contemplado (1946; diterjemahkan dalam bahasa Inggris menjadi Sea of San Juan: A Contemplation) menggambarkan penyair yang berkontemplasi tentang kehidupan dengan keingintahuannya yang dalam dengan mengeksplorasi kehidupan, menemukan nilai-nilai kehidupan, dan kembali untuk menemukan arti hidup. Tema puisi itu adalah laut. Jadi, penyair berhadapan dengan dan berpikir tentang laut, dan mengadakan dialog dengan laut. Dengan demikian, ada dua hal sebagai wujud objek, yaitu laut sebagai fenomena alam dan kehidupan sebagai images. Keduanya menjalin connection. Pertama, koneksi antara tema dan kehidupan. Kedua, tema dengan sejarah budayanya. Ketiga, tema dan variasinya.

Koneksi antara tema dan kehidupan terlihat jelas dari apa yang terjadi pada penyair, yaitu kontemplasi kehidupan melalui laut. Adapun koneksi antara tema dan sejarah budayanya dapat ditelusuri melalui baris-baris yang memuat tentang laut yang menjadi tren sejak zaman Yunani. Laut yang saat itu dihadapi oleh penyair berhubungan dengan laut yang diceritakan di masa lalu. Tarik- menarik antara yang lalu dan yang sekarang adalah juga tarik- 
menarik antara original dan tradisi, antara individualitas dan sejarah. Maka, struktur akan terbentuk berdasarkan dari mana peneliti memulai investigasi melalui kesejarahan (dalam kasus ini, laut yang sekarang dihubungkan dengan laut di masa Yunani). Barangkali di tengah-tengah antara laut yang sekarang dan laut zaman Yunani terdapat laut-laut yang lain secara historis. Maka, struktur diakronis ini akan menghasilkan, misalnya, polaritas zaman modern, yaitu antara dunia masa kini dan rasa kehilangan yang kosong. Arah polaritas dari evolusi laut yang sudah ditemukan kepada makna laut yang muncul di masa modern adalah gambaran bagaimana hubungan antara tema dan sejarah budaya bekerja.

Tema sekaligus objek cerita yang berupa laut dapat dikategorikan wujud tema natural fenomenon (oleh Prawer). Connection secara historis terdapat pada laut yang direpresentasikan pada waktu yang berbeda (antara laut masa lalu sampai laut kini). Polarity-nya terlihat pada hubungan timbal balik antara laut dan makna kehidupan. Misalnya, kekosongan hidup yang melanda di era modern. Jadi, peran sejarah menghasilkan knowledge of collective and definite differences in time as well as in space (Guillen, 1993: 199-201). Polaritas antara dunia masa kini dan rasa kehilangan yang kosong disebut knowledge of collective; laut yang sekarang, laut-laut yang lain, dan laut zaman Yunani menunjukkan definite differences in time as well as in space. Laut sebagai satu-satunya fokus berkembang menjadi makna-makna yang berbeda sebab fokus tersebut berakar dan dikondisikan oleh sejarah. Image-image (laut dari zaman ke zaman) yang muncul merupakan sensibility chanels (makna laut dari zaman ke zaman) dan sekaligus merupakan cara mencapai pemahaman kehidupan (kekinian dan kekosongan) (Guillen, 1993: 204). Seorang peneliti sastra banding adalah orang yang menjadi saksi mata sebuah proses yang terusmenerus; dibaca dan dimitoskan pada karya sastra di dalam kerangka distinct historical societies. Sebuah penetrasi fenomena alam ke wilayah budaya, misalnya, membuktikan investigasi sastra banding pada sisi tema sangat membutuhkan peran sejarah sastra (sebab sejarah yang disampaikan pada contoh di atas berjalan pada koridor terhadap apa saja yang terjadi karya sastra saja) (Guillen, 1993: 209).

Guillen mengusulkan dua hal berkenaan dengan kemungkinan terbentuknya tema baru. Dua hal tersebut adalah fakta sosial dan proses budaya. Contoh analisis tematologi untuk membuktikan pandangannya tersebut terdapat pada analisisnya tentang tema fool (orang bodoh, bukan goblok). Analisis ini diambil dari penelitian Walter Kaiser dalam bukunya Praisers of Folly (1963). Menurut Kaiser, fool mengambil peranan penting pada karya-karya tiga sastrawan terkenal zaman Renaissance, yaitu Erasmus, Rabelais, dan Shakespeare (Guillen, 1993: 210-211). Keberterimaan fool oleh pembaca karya sastra zaman Renaissance merupakan keberterimaan premis-premis, aspirasi, dan momen-momen nostalgik tentang fool. Contohnya, di zaman modern, ada lakilaki ambisius yang pergi mengadu nasib di kota-kota besar; di abad pertengahan, ada peziarah, ksatria hebat, dan tokoh hero dari rakyat jelata. Demikianlah, fool ada di manamana pada masing-masing era. Kehadirannya dihargai karena kesederhanaannya, fool selalu digambarkan sebagai orang yang menikmati kebebasan hidup, dan mengomentari atau mengolok-olok aturan-aturan yang dibakukan. Dimulai dari sini, Guillen mengungkapkan bahwa sebuah tema tidak harus datang dari pergulatan intelektual, tetapi dari realitas hidup, yaitu kejadian yang terlihat dan dialami.

Tema yang berhubungan dengan pergulatan intelektual dapat dimengerti dengan mengingat kembali wujud tema oleh Guillen dan Prawer di atas. Kalau menengok lagi pembicaraan tentang wujud tema, pergulatan intelektual tersebut terdapat pada wujud motif (dalam Guillen) atau the fundamental conditions of buman existence, atau perennial human problems atau recurring situations (dalam Prawer).

Fool, dalam perspektif sejarah, memiliki representasi dan sebutan yang berbeda. Erasmus mengidentifikasi sebagai berikut: "the buffoon of kings, princes, and prelates those of Pope Leo X 
in Italy at the beginning of the sixteenth century; in Spain the jester, the semibuffoon (Charles V's Dr. Villalobos'), Don Francisco de Zuniga, Soplillo, Pabilos of Valladolid, the boobies and dwarves of Valezguez:" Shakespeare dan Ben Johnson juga menggunakan fool pada Henry $V$ dan King Lear. Maka, Kaiser menjuluki fool dengan sebutan "boly simplicity", mengutip Thomas a Kempis, dan "learned ignorance", mengutip Nicolas of Cusa. Sedikit demi sedikit terbukalah jalan bagi "the problematization of rational thought, the praise of folly, and the mixing of jests and thruths" yang akan membawa kisah-kisah semacam Licenciado Vidriera, Master Glass, dan Don Quixote kepada konsekuensi- konsekuensi pentingnya.

Guillen mengkritisi apa yang sudah dilakukan Kaiser bahwa penemuan tentang pengaruh sejarah terhadap keberadaan fool secara historis dan kultur bukanlah sebuah penjelasan yang lengkap. Guillen melihat fool sebagai bagian image yang mewakili keberadaan fool pada umumnya. Oleh karena itu, Kaiser menyajikan selera dan sampel dari fool. Guillen berpendapat bahwa satu tema yang sudah ditentukan tidak dapat difungsikan sebagai synecdoche. Hal ini disebabkan oleh kehadiran fool pada masa Renaissance sampai Reformasi bersandingan dengan the rogue (orang licik). Pluralitas petanda-petanda yang dihasilkan oleh investigasi atas satu tema dalam satu periode menimbulkan perdebatan. Dengan ditemukannya lagi perkembangan keberadaan fool yang sejajar dengan keberadaan rogue di era yang lain, Guillen menyebut gejala ini dengan polysemy, maka dapat ditengarai bahwa interpretasi atas tema dapat berkembang secara sirkular dan "bersayap" Sirkulasi interpretasi dan bervariasinya wujud tema tergantung dari sejarah dan budaya. Ada fakta sosial, yaitu eksistensi fool dan rogue, dan proses budaya, yaitu signifikansi fool dan rogue.

Investigasi secara tematis harus meletakkan terlebih dahulu sebuah kesadaran akan adanya perubahan. Struktur tematis berada dalam inkonsistensi. Inkonsistensi muncul karena adanya aspek sejarah dan budaya mempengaruhi perkembangan dan perubahan struktur tema. Namun demikian, inkonsistensi ini bergandengan satu sama lain pada kesempatan yang bersamaan. Hasil dari hubungan persistence and change menghasilkan possible discoveries and innovative variations (Guillen, 1993: 216). Jadi, keberadaan tema bersebaran di mana-mana, bahkan dalam sebuah cerita. Adalah tugas dari peminat kajian sastra banding untuk mengadakan seleksi terhadap mana yang berarti, mana yang tidak (Guillen, 1993: 126 dan 232), dan mana yang hilang (absence) (Guillen, 1993: 221). Proses penyeleksian dilakukan dengan mata jeli melihat aspek sejarah dan budaya. Kemampuan melihat, menyeleksi, dan membidik ini disebut kemampuan eidetic dalam pembicaraan tentang fenomenologi oleh Budi Darma (2004: 100-103). Semakin banyak pengetahuan dari sisi sejarah dan budaya, semakin banyak kemungkinan tema yang terdeteksi dan semakin ketat penyeleksian tema sebagai bahan investigasi. Penyeleksian yang paling mudah, menurut Guillen, dilakukan ketika tema-tema budaya diperbincangkan, misalnya mitos Golden Age, ide tentang manusia sebagai mikrokosmos, dan sebagainya (Guillen, 1993: 126).

Guillen mengapresiasi Elizabeth Frenzel yang menyumbangkan ide tentang tematologi, yaitu membedakan antara primary theme dan principal motif. Keberadaan dua istilah ini mendorong peneliti sastra banding untuk tidak memandang ringan penentuan tema yang secara implisit dapat dirasakan pada uraian paragraf di atas. Primary theme adalah materi yang dikumpulkan dan digunakan oleh pengarang, sedangkan principal motif adalah situasi yang signifikan yang dielaborasi oleh pengarang. Jadi, keberadaan rogue merupakan primary theme pada Othello karya Shakespeare pada contoh munculnya polysemy di atas, sedangkan bagaimana hasutan rogue yang membisikkan dusta mempengaruhi Othello untuk melakukan hal-hal jahat, misalnya membunuh Desdemona demi kekuasaan, merupakan principal motif. Dapat disimpulkan bahwa primary theme dan principal motif adalah dua entitas yang saling mendukung dan mengisi. 
'For him 'Motiv' is what makes the argument possible objectively, what invites its composition: the intrigue, fable, or 'mythos' of Aristotle. 'Thema' is the personal and subjective attitude of the writer face to face with what life and literature suggest to him.... Motifs are given, found, or invented; and without them it is difficult to find an approach to a drama or a novel. The theme is inescapable destiny of the writer" (Guillen, 1993: 234).

Kutipan di atas mengandung arti bahwa tema ibarat sebuah lembaga yang perlu digerakkan oleh agen, yaitu motif. Hal ini sudah disinggung pada penjelasan sebelumnya.

Di halaman lain, Guillen (1993: 236) menyatakan bahwa tema berjalan dengan kemisteriusannya sebab tema seperti bayangan yang tergeletak menunggu natural links (istilah Harry Levin) dengan archetypal sourcenya. Dengan demikian, penemuan tema dapat ditelusuri terlebih dahulu pada motifnya. Maka, "All themes and characters and stories that you encounter in literature belong to one big interlocking family" demikan Frye dikutip oleh Guillen (1993: 237). Natural links, archetypal source, dan one big interlocking family mengarah pada supranasional.

Penelusuran keterhubungan (natural links) tema yang sekarang dan yang lalu (archetypal source) disebut dengan tematologi. Tematologi bekerja dengan sejarah sastra dan budaya sekaligus. Sejarah berperan sebagai alat menghubungkan, sedangkan budaya berperan sebagai alat pemberi makna pada evolusi tema dan motif. Struktur yang terbentuk dari rangkaian tematis menciptakan supranasional (one big interlocking family). Dengan demikian, tematologi membawa misi unity untuk membangun struktur dari diversity karya-karya sastra yang bertebaran dalam waktu dan ruang. Tema dianalisis untuk mencari perannya dalam melacak hadirnya supranasionalitas.

\section{Kesimpulan}

Guillen merekomendasikan pengerjaan penelitian sastra banding dilakukan dengan menggunakan lebih dari dua karya sastra. Hal ini ditujukan untuk menelusur subjek penelitian sampai pada arketipnya. Khusus pada kelas tematologi, peneliti diarahkan untuk menentukan terlebih dahulu tema yang menarik untuk dikaji. Yang dimaksud dengan tema bukan tema cerita dalam karya sastra tetapi fenomena yang tersebar pada seluruh cerita. Penentuan tema menghasilkan identifikasi motif yang mendorong tema (fenomena) terjadi. Dari langkah ini motif utama akan ditemukan. Dengan menggunakan alat motif utama dialektika dapat dibentuk. Dialog ini disebut dengan internasionalitas. Internasionalitas mengarah pada pembentukan struktur diakronis untuk melacak keberadaan tema secara kronologis sampai pada arketipnya (yang paling tua di antara karya sastra yang dibandingkan) dimana peranan sosio dan historis menjadi penting. Sebagai akhir penelitian, supranasionalitas merupakan ide besar alasan hadir tema. Supranasional berbentuk abstrak dan luas. Jadi, wilayah pembandingan yang dituntut Guillen sangat luas dan dalam sebab ia tidak menghadirkan persamaan dan perbedaan saja tetapi alasanhadir dan kesadaran apa yang sedang terjadi. Oleh karena itu judul teori sastra banding Guillen ini The Challenge of Comparative Literature sebab memang pada hakikatnya teori Guillen menantang kemampuan peneliti untuk menguak tabir peta pemikiran sejarah perjalanan sastra.

\section{Daftar Pustaka}

Darma, Budi. 2004. Pengantar Teori Sastra Jakarta: Pusat Bahasa Departemen Pendidikan Nasional.

Guillen, Claudio. 1993. The Challenge of Comparative Literature. Terjemahan oleh Cola Franzen. Cambridge: Harvard University Press.

Kaiser, Walter. 1963. Praiser of Folly. De Gruyter. Cambridge: Harvard University Press.

Wellek, Rene. 1965. History of Modern Criticism: 1750-1950. New Heaven: Yale. University Press. 